\title{
The impact of export processing zones on employment, wages and labour conditions in developing countries: systematic review
}

\author{
Xavier Cirera ${ }^{a}$ and Rajith W. D. Lakshman ${ }^{b}$ \\ aTrade and Competiveness Global Practice, the World Bank; ${ }^{b} C i t i e s$ Cluster, Institute of Development Studies, \\ Brighton, UK
}

\begin{abstract}
One of the most common instruments of industrial policy is Export Processing Zones (EPZs). This paper shows the results of a systematic review of the impact of EPZs on employment, wages and labour conditions in developing countries. The results of synthesising 59 studies suggest that there is no robust evidence that the employment created in the zones is additional. Also, in most cases, EPZs pay higher wages and do not contribute to increase the gender wage gap. The results regarding labour conditions such as health and safety, unionisation or hours worked are mixed when comparing with firms outside the EPZ.
\end{abstract}

\section{ARTICLE HISTORY}

Received 19 August 2016

Accepted 14 March 2017

\section{KEYWORDS}

Export processing zones; systematic review; employment; wages; labour conditions; developing countries

\section{Introduction}

One of the most common instruments of industrial policy in developed and developing countries are Export Processing Zones (EPZs). The ILO defines an EPZ as 'industrial zones with special incentives set-up to attract foreign investors, in which imported materials undergo some degree of processing before being exported again' (ILO 1998, 3).

EPZs largely proliferated after the Second World War, and have evolved in different ways according to each country's policies. This expansion of EPZs was largely driven by the introduction of export-led growth strategies. In some countries, EPZs can include entire provinces, like in China, while in others EPZs include single firms. The type of activity within the zone has also evolved, with some countries moving from labour-intensive to technology-intensive sectors, or even including services sectors such as tourism.

The large proliferation of EPZs is an indication of the importance of this instrument for industrial policy and export-led growth. However, despite the increase and spread in the number of zones, there is little evidence on the additional effect that these instruments have on employment and wages. More importantly, EPZs have been heavily scrutinised by civil society, often accused of employing a 'race to the bottom' strategy in terms of labour conditions (ICFTU 2004).

Although there is a large amount of literature in this area, including a few surveys, no attempt has been made to collect, review and synthesise all the available evidence on EPZs and labour outcomes using a theory of change model suggested by the theoretical literature.

The objective of this systematic review is, therefore, to identify the impacts that EPZs have on additional employment created, the wage level and labour conditions. Regarding labour conditions, we focus on the impacts on three key elements: freedom of association, working hours and 
health and safety. It is also an objective of the review to evaluate whether there is a specific gender impact related to these outcomes.

We present the intervention and the hypothesised pathways through which EPZs may affect outcomes in Section 2. We then discuss the methods of search, inclusion and critical appraisal in Section 3. In Section 4, we present results. Finally, Section 5 discusses implications.

\section{EPZs and employment outcomes}

Many developing countries and some regions in developed countries experience low investment in manufacturing sectors, especially in those with more value added. EPZs are an attempt to achieve more manufacturing exports, industrial sector upgrading and employment creation in manufacturing.

Different zones provide different types of incentives, depending on the existing domestic market conditions, ability to attract Foreign Direct Investment (FDI) and the type of sectors targeted to be attracted to the zone. This makes the comparison across EPZs difficult. In general, we can separate the main set of incentives in three categories: tax, infrastructure and regulation, as suggested in Table 1. The size of the incentive and subsidy offered also depends on the general conditions of the economy. For example, in countries with a difficult business environment, the size of these incentives is likely to be large. In addition, the impacts of EPZs on labour outcomes depend on the sector composition of the EPZ. In EPZs concentrated in labour-intensive sectors such as clothing, derogations to minimum wages may play an important role in attracting FDI. In other sectors, such as electronics, minimum wage derogations may not have greater impacts since they tend to pay higher wages.

EPZs by definition are not first best interventions, since they do not directly address some of the problems that may constrain manufacturing growth. Instead, they introduce distortions in order to attract investments in specific sectors that a priori would not be attracted to the country or region. In addition, governments use EPZs as an instrument to attract investment in sectors with no clearly defined comparative advantage or as a way of increasing value added in existing export activities.

As a result of the distortionary nature of the intervention, most theoretical analyses on EPZs have focused on their welfare impacts. Hamada (1974), for example, using a Heckscher-Ohlin model shows that if investment flows to the EPZs are oriented towards producing a capitalintensive good which is protected by a tariff in the domestic economy, then labour will flow from labour-intensive activities in the domestic economy to the EPZ. This will in turn amplify the distortion imposed by the tariff. Two critical assumptions of the model are the fact that the labourintensive product is not produced in the EPZ and that there is full employment. When these two assumptions are relaxed, the EPZ is not welfare decreasing (Hamilton and Svensson 1982; Young and Miyagiwa 1987).

Table 1. EPZs main incentives.

\begin{tabular}{|c|c|}
\hline Tax exemptions & $\begin{array}{l}\text { - Export taxes } \\
\text { - Import taxes on inputs } \\
\text { - Profit and property taxes, and other direct taxes } \\
\text { - VAT }\end{array}$ \\
\hline Regulation exemptions & $\begin{array}{l}\text { - Exemptions from foreign exchange controls } \\
\text { - No controls on profit repatriation } \\
\text { minimum wages }\end{array}$ \\
\hline Infrastructure incentives & $\begin{array}{l}\text { - Specific streamlined government services - that is, custom services, business registra- } \\
\text { tion and so forth. } \\
\text { - Provision of enhanced specific infrastructure for production, logistics and transport - } \\
\text { that is, better roads, free or subsidised lease of land or industrial plants and so forth. } \\
\text { - Subsidised prices in public utilities such as electricity or water }\end{array}$ \\
\hline
\end{tabular}


While evaluating the impact of EPZs requires consideration of all these factors, this review focuses on a very specific set of labour market outcomes. Regarding labour markets, Young and Miyagiwa (1987) show that in the presence of Harris-Todaro type of unemployment due to wage rigidities in urban areas, the reduction in the tariffs for intermediate inputs in EPZs increases wages in non-unionised sectors, reducing the gap with unionised wages and decreasing unemployment. Gupta (1994), however, using a similar model suggests that a reduction on the tariff on intermediate inputs in EPZs will result in lower national income and employment. On the other hand, if there is a reduction of the final good tariff, employment and income will grow. Finally, Din (1993) shows that under certain assumptions, the key element that will determine a beneficial impact of investment on the EPZ on employment is whether the 'enclave' sector is capital intensive in relation to the domestic manufacturing sector.

It is important to highlight that these theoretical models focus mainly on the effect driven by tariff reductions within the EPZ. One set of incentives, however, that is crucial for the impact on the labour market, as we will see below, are derogations of some labour laws. The theoretical impact of these incentives has not been addressed, and may play an important role regarding labour conditions.

A final important element regarding labour market outcomes of EPZs that has not been addressed by the theoretical literature is the impact on the feminisation of labour within the zone. The sector composition of EPZs and some of the derogations of labour law may have a differentiated impact on gender (that is, larger female employment, increase in the gender pay gap and worse labour market conditions for women within the zone).

Figure 1 presents the logic model of change to fully understand how EPZs are expected to affect labour market outcomes. The model focuses only on direct effects on labour market outcomes.

The Figure shows how the different set of incentives described above are expected to attract additional investment to locate in the zones. This has an impact on employment, wages and labour conditions within and outside the area, and in each of these outcomes the literature identifies a potentially differentiated gender impact.

It is important to highlight the fact that these labour market outcomes should be considered in relation to the domestic economy. Regarding employment, the theoretical models reviewed are unclear about whether the EPZ is only absorbing existing labour from domestic sectors or is

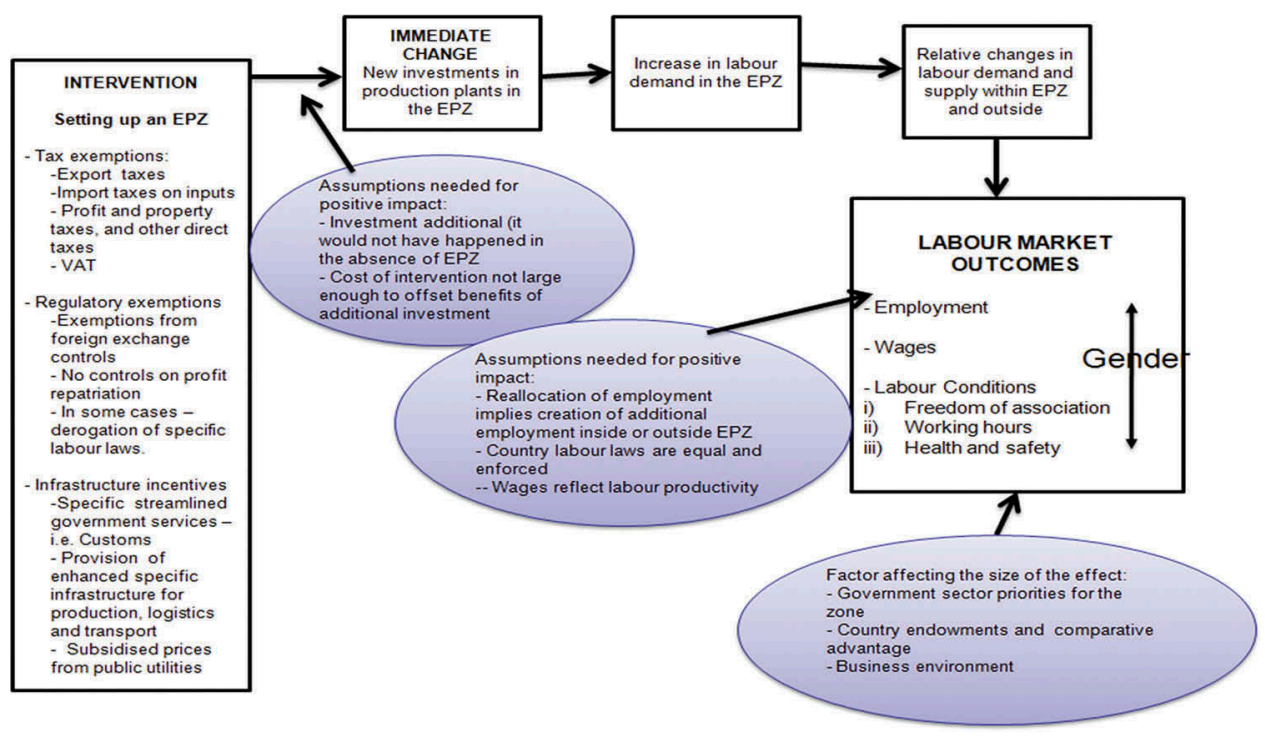

Figure 1. The logical model. 
creating new jobs. Similarly, the impact on wages has two dimensions. First, the question is whether EPZs pay more or less wages than they would if they were in the domestic economy. This is more important in cases where there are derogations of minimum wages within the zone. The second dimension is whether the EPZs have an impact on the wage level of the entire economy.

In cases where there are derogations of labour laws, it is possible that labour conditions within the EPZ are affected. In this review, we focus on three main elements: freedom of association, hours worked and health and safety conditions.

Finally, a cross-cutting element across the three types of labour outcomes is the gender impact. Regarding employment, there is some evidence that EPZs tend to employ more women than men. A key question, however, is whether this is due to the sector composition of the EPZ, traditionally more female-intensive sectors, or a preference of EPZs.

The extent of the impact or effectiveness of the interventions depends critically in a set of contextual factors. First, there is the type of sector attracted to the EPZ. Negative outcomes on labour appear to be correlated mainly with labour-intensive sectors such as clothing, footwear and low-skilled electronics. Second, the type of labour institutions and the capacity to enforce the law is also important, since negative labour outcomes may occur on both the EPZs and the domestic economy when institutional capacity is weak.

\section{Methods}

\section{Inclusion criteria}

The review includes only primary research studies which document impacts of EPZs in low- and middle-income countries as defined by the World Bank. We focused on workers employed in firms located in EPZs and not impacts on domestic suppliers to these firms located outside the EPZ. As suggested above, the incentives granted vary by EPZs. However, given the complexity of quantifying all the incentives, we treat all EPZs as a similar intervention. ${ }^{1}$ This caveat needs to be kept in mind when interpreting the results.

Studies were eligible which collected data on the following outcomes: additional employment, wages, working hours, freedom of association/right to unionisation health and safety, and any gender differentiated impact on these outcomes. Studies that looked at the impact of incentive zones in developed countries or the impact of EPZs on exports, linkages, spillovers or investments were excluded.

Regarding the methodologies to be included in the review, we implemented a variable approach according to the outcome variables to be analysed. For employment, we included studies with contemporaneous comparison groups which attempted to measure additionality using counterfactual methods - that is, in relation to comparable workers outside the EPZ. For wages, we also included before versus after studies. In relation to labour conditions, given the lack of studies with appropriate comparators, we also included factual studies - that is, studies which only collected data among populations in EPZs and did not use counterfactual methods; although these are discussed separately in the synthesis. The full list of inclusion criteria can be found in Cirera and Lakshman (2014) (see summary in Table 2).

\section{Literature searches}

We conducted systematic searches for published and unpublished literature. Figure 2 describes in detail the search results including the number of citations identified in all of the electronic databases: Web of Science (this included Social Sciences Citation Index, Arts \& Humanities Citation Index, Conference Proceedings Citation Index - Social Science \& Humanities), IDEAS, International Bibliography of Social Science (IBSS), EconLit, JOLIS, Google Scholar and ILO's 
Table 2. PICOS Table.

\begin{tabular}{|c|c|c|}
\hline Parameter & Inclusion criteria & Exclusion criteria \\
\hline Problem/population & $\begin{array}{l}\text { Workers and households in low- and middle- } \\
\text { income countries as defined by the World } \\
\text { Bank. }\end{array}$ & Populations located in high-income countries. \\
\hline Intervention & $\begin{array}{l}\text { Export processing zones (also known as free } \\
\text { zones, industrial zones, special economic zones } \\
\text { or free trade zones) created with special } \\
\text { incentives }\end{array}$ & $\begin{array}{l}\text { Other interventions to support manufacturing } \\
\text { through alternative industrial policy } \\
\text { instruments such as subsidies }\end{array}$ \\
\hline Comparator & Workers employed outside the EPZ & Workers employed within the EPZ \\
\hline Outcomes & $\begin{array}{l}\text { Additional employment/investment, wages, } \\
\text { labour standards (freedom of association, } \\
\text { working hours, health and safety). Outcome } \\
\text { differences between men and women workers }\end{array}$ & $\begin{array}{l}\text { Exports, linkages, spillovers or investment, } \\
\text { Intra-household gender outcomes. }\end{array}$ \\
\hline Study design & $\begin{array}{l}\text { For employment, investment and wages, primary } \\
\text { research studies which used a comparison } \\
\text { group with counterfactual estimation (for } \\
\text { example, multivariate regression analysis) to } \\
\text { estimate impacts attributable to the } \\
\text { intervention. In the case of wages, these also } \\
\text { included evaluations collecting data before } \\
\text { versus after intervention. For labour standards, } \\
\text { studies which collected data on EPZ workers } \\
\text { only were also eligible. }\end{array}$ & $\begin{array}{l}\text { Studies assessing the relation between exporting } \\
\text { and FDI processes and labour outcomes that } \\
\text { do not focus on assessing EPZ interventions. } \\
\text { Studies using secondary data, including other } \\
\text { reviews. }\end{array}$ \\
\hline Accessibility & Accessible reports & $\begin{array}{l}\text { Confidential or non-accessible full reports online } \\
\text { or previous request through email }\end{array}$ \\
\hline
\end{tabular}

Resource Guide on EPZs. In total we found 1,393 studies out of which 1,080 were unique, and we included 59 of these in this review. The detailed list of studies can be found in Cirera and Lakshman (2014).

\section{Data collection}

We collected data on the contextual factors, methods of analysis and outcomes reported. We assessed the extent to which the study was able to determine a causal relationship between the intervention and outcomes using information about the comparison group and methods to control for confounding variables. We collected the following primary outcomes measures:

- Employment effect - the coefficient for included studies that measured additional employment created or the net employment effect. It also includes the coefficient that measured the gender effect.

- Wage effect - the coefficient for included studies that measured the impact of the EPZ on wages, controlling for other factors that may affect individual wages and the gender gap. Also includes comparisons of wage levels between groups inside and outside the zone.

We also extracted qualitative information regarding labour conditions. Concretely, we focused on three main outcomes:

- Freedom of association - whether this was allowed within the area and the percentages of the labour force unionised inside the EPZ compared with the rest of the economy, including data disaggregated by sex if information available.

- Working hours - any information regarding working hours in the EPZ and in comparable sectors outside the EPZ, including data disaggregated by sex if information available.

- Health and safety - any information regarding health and safety conditions and in comparison with conditions in the rest of the economy. 


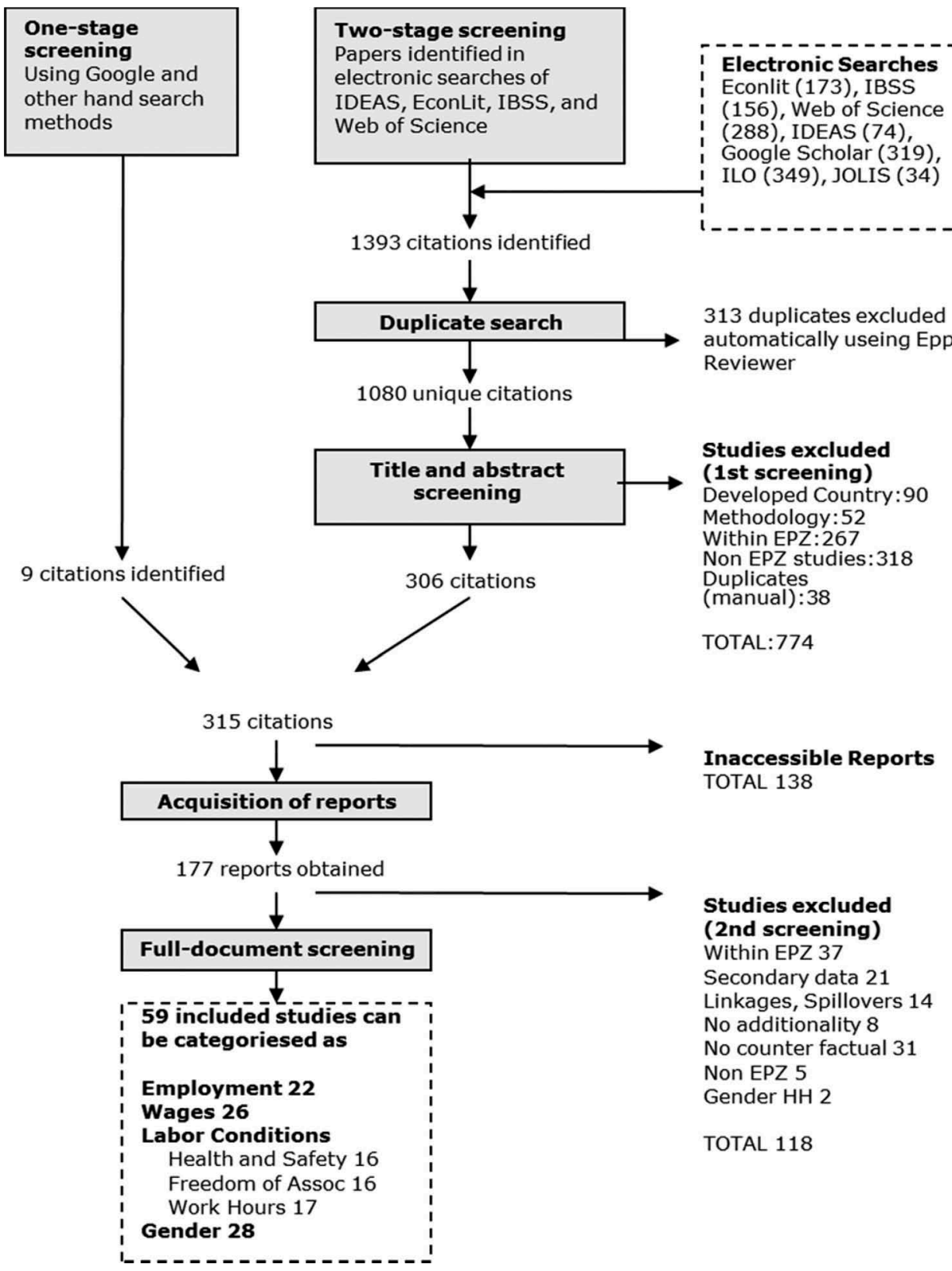

Figure 2. Summary of searches.

\section{Results}

\section{Employment}

The level of employment in EPZs has increased substantially in developing countries. In 2002, employment was estimated as 30 million in China and 13 million (up from 4.5 million in 1997) in other countries (ILO 2003b). In 2006, the figures were increased to 40 million in China and 26 million elsewhere (Singa Boyenge 2007). However, it is not clear that the employment created in EPZs is additional. Additionality is very difficult to measure empirically given the lack of data about a 
counterfactual (that is, would a company have invested anyway outside the zone). Moreover, there are two levels of additionality that are relevant: additionality of investment and additionality of employment - investments are created and not reallocated from outside the zone.

\section{Additional investment}

A few studies have tried to address the issue of additionality. Aggarwal $(2007,2010)$ attempts to address the issue of additionality of employment linked to whether investments are additional in Indian EPZs. Aggarwal (2007) emphasises two elements. First, investments in the EPZs are different from FDI outside the zone; the former has an export focus and the latter a domestic market focus. Second, the author argues that, given the poor investment climate in India, investment in special zones would not have occurred without the incentives. The author concludes that the impact of the new investments in EPZs is 687,565 new jobs; which is not significant nationally, but important for some local areas. No evidence, however, is provided about the extent of additionality and the role of EPZ in attracting this investment.

Aggarwal (2010) also looks in more detail at the issue of reallocation of investment in the zones in India, by assessing quantitatively the trends of industrial investment outside the special economic zones (SEZs). The author does not find any major changes in the trend around introduction and expansion of SEZs, and concludes that there is no evidence of reallocation of investments.

Clearly, evidence in this area is too thin to reach any conclusions, and the question of whether some of this FDI would have occurred in the economy without EPZ incentives is largely unanswered.

\section{Workers' reallocation}

A different set of studies has focused on analysing the evidence in relation to worker reallocation. Some studies have used surveys on EPZ workers to ask about previous occupations. A second set of studies have focused on tracing EPZ workers' migration flows prior to entering the EPZs.

Starting with analysis of previous occupations, Aggarwal (2007) suggests that the fact that most workers in India's zones are concentrated in the 20-29 years old cohort is evidence that EPZ workers are freshly entering the job market, which is an indication of additionality to net job creation. Yonghong (1989) also uses a survey of workers for China to analyse their previous occupation. The author finds a mixture of results; $54 \%$ of workers previously working (38\% in factories and $16 \%$ in farms) and $46 \%$ previously not working (32\%) or waiting for a job (14\%). This indicates a mixture of both, jobs being reallocated and workers entering the labour market.

Zohir (2001a) also finds evidence of job reallocation from outside to inside the EPZ in Bangladesh. Around one-third of female workers and two-third of male workers were employed prior to their employment in the EPZ, and from those employed, most were employed in the garment industry outside the zone. The author found a high degree of reallocation for men attracted by higher contract security inside the EPZ. ${ }^{2}$

A second set of studies have focused on migration flows of EPZ workers. Aggarwal (2007) finds that only $20 \%$ of workers migrated to the zones, indicating no major rural to urban reallocation of workers. Zohir (2001a) finds a different picture for Bangladesh, with about $72 \%$ of women and $68 \%$ of men workers were migrants, and that migrants are a larger proportion in non-garment sectors. As before, whether migrants or not, one needs to consider the previous occupation of workers in rural areas to determine the effect on net employment.

In general, the few studies reviewed suggest that EPZs absorb both existing workers and new workers entering the labour market. A critical element here is likely to be the skill intensity of workers required in the EPZs. Zones that have more skill-intensive sectors are more likely to reallocate existing workers in similar sectors, while zones with low skill-intensive sectors are more likely to employ new entrants. Sanders and Brown (2012), however, suggest that in some cases where pull factors from EPZs on migration flows are very large, EPZs can create significant regional unemployment. This last effect may be more important in downturn periods. 


\section{Employment and gender}

Most of the studies reviewed indicate greater female than male employment in EPZs. These include Cling, Razafindrakoto and Roubaud (2005), Cling, Razafindrakoto and Roubaud (2007) and Glick and Roubaud (2006) for Madagascar; Dunn (1999) for Jamaica, Barbados and Belize; Mathews (1994) and De Moya (1986) for the Dominican Republic and Alvarenga and Ligia (2001) for El Salvador. Aggarwal (2007) for India and Fu and Gao (2007) for China find more male employment in EPZs; while De Armas and Jallab (2002) find similar proportions.

In addition, EPZs tend to employ more women than other sectors outside the zone. Farole and Akinci (2011) suggest that for various countries EPZs have almost doubled the female share of nonagriculture sectors. Fu and Gao (2007) report around 10\% for China, while Alvarenga and Ligia (2001) for El Salvador and Cling, Razafindrakoto and Roubaud $(2005,2007)$ for Madagascar find more EPZ female employment than private sector firms outside and government. The problem with these studies is that the comparison is carried out between different sectors of activity.

In order to analyse whether this feminisation of employment effect is the result of the sector composition of activities within the zone, we need to compare equivalent sectors inside and outside the EPZ. We found one study by De Moya (1986) for the Dominican Republic, which compares the same manufacturing sub-sectors and finds much larger female employment shares in EPZs. This is evidence that in addition to the sector composition of EPZs, EPZs tend to employ more women in some countries; although we need more evidence on other countries to fully test this hypothesis.

A final set of studies analyse whether EPZs increase female participation in the labour market. These studies mainly use surveys asking women about past occupations. Yonghong (1989) for China, Zohir (2001b) for Bangladesh and Hein (1984) for Mauritius find evidence of women entering the labour market through EPZs.

Summarising, the evidence reviewed gives some support for the feminisation of labour hypothesis in EPZs. Most EPZs tend to employ more female than male labour, although there is significant heterogeneity across countries. This is mainly the result of the sector composition of EPZs, more female intensive; although we found one study suggesting that even when comparing the same sectors EPZs employ more women. Finally, the studies reviewed suggest that EPZs contribute to increasing female participation in the labour market.

\section{Wages}

One frequent critique of EPZs by trade unions and civil society in some countries has been that firms located in the zones pay lower wages than they would pay if located outside the zones. However, most of the studies reviewed indicate that EPZs pay higher wages. ${ }^{3}$ Only five studies find lower wages were paid in EPZs, ${ }^{4}$ and a few other studies present a more complex picture depending on the type of sector. Zohir (2001b) for Dhaka EPZ in Bangladesh finds higher wages in the zone for female but lower for male, compared with firms outside the zone. Glick and Roubaud (2006) find for Madagascar, wages in the EPZ to be higher than informal but lower than other private sectors. Warr (1987) in the Philippines finds the same wage for low-skill workers inside and outside the zones, and higher wages inside the EPZ for skilled workers. Finally, Cling, Razafindrakoto and Roubaud $(2005,2007)$ find a wage premium associated to EPZ that is no different from the formal private sector and is higher than the informal sector.

One problem of these studies is that they do not control for the sector and skill composition. However, a small group of studies use econometric techniques to estimate the wage premium associated with EPZs in earning equations. The main advantage of these studies is the control for the level of skills of individual workers and other external factors. The findings of these studies (Cling, Razafindrakoto, and Roubaud (2005, 2007), Fussell (2000), Kabeer and Mahmud (2004) and Glick and Roubaud (2006)), show that EPZs pay better than the informal sector, but when comparing with the formal sector the results are inconclusive. 
In general, the results suggest significant heterogeneity in relation to wage differentials between firms inside and outside the zones. In most cases, firms in EPZs tend to pay higher wages, but there are some cases where there is evidence of the opposite.

A final element that we have analysed in relation to wages is the impact of EPZs on the gender wage gap. For the Dhaka EPZ in Bangladesh, Zohir (2001a, 2001b) documents a larger wage gap within the zones, although it is similar to factories outside the EPZ. However, Joekes (1987) for the Dominican Republic, Soni-Sinha (2010) for India (Uttar Pradesh) and Hein (1984) for Mauritius suggest that there is no impact of EPZs on the gender wage gap, and if any it is smaller in EPZs.

\section{Labour conditions}

We focus the analysis in three elements of labour conditions: unionisation, health and safety and working hours.

\section{Unionisation}

There is evidence that union rights have been legally constrained or de facto discouraged in EPZs. Dunn (1999) suggests that unionisation in EPZs is discouraged in Jamaica, Barbados and Belize. Gopalakrishnan (2007) provides examples of restrictions on union rights in several countries. ${ }^{5}$ Evidence of union rights violations are also documented in ICFTU (2003) for Bangladesh, Philippines, Lesotho, Sri Lanka and China; and ILO (1996) for Central America and Dominican Republic during the 1990s. These are confirmed by the ILO global surveys (ILO 2001a, 2001b), although these global studies also document cases where the right of unionisation is also respected in many EPZs. Union rights violations, however, may also prevail outside the zone, and, therefore, rather than an EPZ-related issue, it is also a countrywide problem. ${ }^{6}$

Studies that compare unionisation rates inside and outside the zone suggest mixed results and similar unionisation rates. Cling, Razafindrakoto and Roubaud (2005) and Glick and Roubaud (2006) for Madagascar, find more unionisation in EPZs than in the private sector outside, although the authors compare different sectors of activity. Mireri (2000) also finds more unionisation inside the EPZ even when unionisation is effectively discouraged in the zone. Finally, Kabeer and Mahmud (2004) in the only study that compares the same sector, garments in Dhaka, Bangladesh, and its peri-urban outskirts in 2001, also finds more unionisation inside the EPZs, although very low for both, $5 \%$ versus $1 \%$. In all of these studies, unionisation inside the EPZ is higher than outside but with similar levels.

ILO (1988) for some Asian countries in the early 1980s and Sen and Dasgupta (2008) for India in 2004-2006, find very similar unionisation rates between firms inside and outside the zone. Only two studies find less unionisation in EPZs. Ver Beek (2001) for Honduras in 1998 finds less unionisation inside the EPZ and Zohir (2001a) for Bangladesh suggests that unionisation is banned inside the zones but not outside. ${ }^{7}$

In general, the results suggest that there is a significant amount of factual evidence documenting restrictions to unionisation inside the EPZs, either through limits on rights or by de facto constraining these rights. However, when looking at the evidence of studies that compare firms inside and outside the zones, the results suggests that in a majority of cases unionisation in the zone is slightly higher or similar than in firms outside the zone. Therefore, excluding those cases where unionisation is restricted by law in EPZs, we cannot conclude whether restrictions to union rights should be attributed to EPZs rather than general failures in domestic labour institutions.

\section{Health and safety}

A set of studies has analysed health outcomes between men and women working in EPZs. Khan, Ullah and Azam (2010) in Pakistan, Hayatabad Industrial Estate Peshawar, finds that female workers experience higher prevalence of mental health disorders than men. Also, Del Prado-Lu (2008) for 
the Philippines in 2002-2006, finds a higher incidence of illness among women workers in the electronics and garment industries in EPZs. Finally, Zohir (2001b) finds that illness incidence in garment EPZs in Bangladesh is higher for female than male. The results also show a higher prevalence for work-related illness in women.

Some studies have used more representative surveys in order to compare health outcomes inside and outside EPZs among women. Liberato and Fennell (2007) show that in the Dominican Republic working in EPZs negatively affect health and increases the likelihood of women to be hospitalised. Guendelman and Silberg (1993) find no impact of the maquila in Tijuana, Mexico, on women's depression or control over life, compared with other activities. Also, Hovell et al. (1988) find no morbidity differences in women working in the maquila and other sectors.

The studies reviewed, therefore, suggest a mixed picture. While there are significant health and safety issues in EPZs documented in the literature, ranging from anecdotal evidence to more robust studies, the few studies reviewed comparing workers inside and outside the EPZs show conflicting results.

\section{Working hours and compulsory and underpaid work}

Those studies that compare working hours inside and outside the zones show mixed results. Three studies find lower working hours in the zones, ${ }^{8}$ two studies find very similar ${ }^{9}$ and three studies suggest longer working hours in the EPZs. ${ }^{10}$

While the number of hours worked are important to determine excessive work, two critical elements for labour conditions are (i) whether overwork is compulsory, and (ii) whether overwork is unpaid. Several studies document compulsory overwork in EPZs. Hein (1988) and ILO (2001b) suggest that there is compulsory overwork for Mauritius apparel EPZ, as does Yonghong (1989) for Shenzhen EPZ in China. Although, there is some anecdotal evidence of workers having problems in getting paid for overtime work (ILO 2001a), we could not find many studies documenting these problems.

Overall, the evidence suggests that while long working hours appear to be a common element in many EPZs, the comparison with working hours outside the zone is mixed. There is, however, evidence that in some countries overwork is compulsory and anecdotal evidence that in some cases overwork is not appropriately remunerated.

\section{Analysis of heterogeneity}

The tables in Appendix 1 summarises the main results in order to identify patterns that may explain the heterogeneity of results.

\section{Sector composition}

One element that emerges from the analysis is the extremely large representation of the clothing and apparel sector in these studies. This is interesting since the inventory of existing EPZs presented in Singa Boyenge (2007) suggests much more sector diversification in existing EPZs, and raises the question of whether this sector is more prone to potential labour outcome problems. However, a closer look at the relationship between sector and impact on labour outcomes does not suggest any clear links.

\section{Period of analysis}

One important element to explain impact is the evolution of the sector composition within EPZs over time. While some countries have EPZs very much focused on pure assembling, others have changed the sector composition towards services or more skilled sectors. Even within sectors, the way processing is carried out has changed substantially in the last 20 years. In addition to the changes in production and the adoption of private labour standards, there has been also a substantial pressure on multinational enterprises to respect labour standards and on countries 
to adopt ILO labour conventions. Decomposing the studies by period, however, does not suggest that studies based on the 2000 s period find better labour outcomes than studies based on the previous two decades. Therefore, the period of study does not explain the heterogeneity of results.

\section{Geographical concentration}

Another possibility is that positive or negative outcomes are concentrated in specific countries and regions. When decomposing geographically the results, four important elements arise. First, most studies included with comparison groups tend to concentrate on a dozen of countries: EPZs in Bangladesh, Sri Lanka, Mexico, Philippines, D.R., Madagascar or Mauritius. Although EPZs are relatively important in these countries, there are other countries such as Malaysia or countries in North Africa, where EPZs are perhaps equally important but have been less scrutinised. This suggests some non-randomness in the focus of enquiry. Second, there are a few cases where studies that analyse the same outcome and the same country suggest slightly different results: for example, India, Madagascar or the Philippines for wages; Bangladesh for unionisation and India for working hours. This may be the result of different periods of analysis but is more likely due to different comparison groups. Third, there is no clear region where labour outcomes appear to be more negative than others. Fourth, there are a few countries where none of the included studies suggest any negative impact on labour outcomes of EPZs as compared with firms outside. These include Madagascar, the Philippines and China. Also, no country with more than one evaluation has only negative labour outcomes inside the EPZ compared with firms outside.

Overall we need to be cautious interpreting the results given the fact that the number of included studies with comparison groups inside and outside the zones is very small. The concentration of studies in the clothing sector and in a dozen of countries is striking and not explained by using only criteria of employment or production share importance. It is possible that the concentration of evaluations on a dozen countries is based on interest based on previous anecdotal evidence of labour disputes, which could indicate some type of publication bias.

\section{Summary and policy implications}

The main conclusions of this review are summarised in Table 3. For employment, the review of the literature does not successfully address whether the employment created in EPZ is additional. However, it is likely that a significant share is additional since in some countries EPZs employ a significant number of new entrants to labour markets and there is no evidence of reallocation of plants from outside to inside the EPZ. This conclusion is, however, tentative since whether EPZ investments would have happened in the absence of the EPZ has not been successfully addressed. To this end, it is imperative to generate more evidence that uses some type of control group. ${ }^{11}$ Furthermore, the review finds some weak support for the idea of feminisation of the labour force in $E P Z s$, although this is difficult to disentangle from the sector composition of EPZs, and a positive impact of EPZs on female labour participation.

In relation to wages, there is significant heterogeneity of results across countries, but in most case studies wages are larger within EPZs, and although the male-female wage gap prevails within the zones, it is not larger than for firms outside the zone.

The review also analysed the evidence on the impact on labour conditions. Some studies have identified specific restrictions in some EPZs on unionisation and labour rights. However, we cannot conclude whether the restrictions should be attributed to EPZs or rather to general failures in domestic labour institutions. The evidence regarding health and safety issues is mixed. In some cases, there is evidence of health and safety problems associated to EPZs, but when compared with workers outside the EPZ, the evidence is mixed. Paradoxically, despite potential larger incidence of health problems in the EPZs, workers inside the zones appear to have better health coverage. 
Table 3. Summary of findings.

\begin{tabular}{|c|c|c|c|c|c|c|}
\hline \multirow[b]{2}{*}{ Outcome } & \multirow[b]{2}{*}{ Nature of evidence } & \multirow[b]{2}{*}{ Impact } & \multicolumn{4}{|c|}{ Number of studies } \\
\hline & & & $\begin{array}{c}\text { Comparison } \\
\text { group }\end{array}$ & $\begin{array}{l}\text { Control for } \\
\text { other factors }\end{array}$ & $\begin{array}{c}\text { Can determine } \\
\text { causality }\end{array}$ & Total \\
\hline $\begin{array}{l}\text { Additionality of } \\
\text { employment }\end{array}$ & $\begin{array}{l}\text { Very limited literature. } \\
\text { Existing study } \\
\text { designs on } \\
\text { employment do } \\
\text { not address } \\
\text { successfully the } \\
\text { issue of } \\
\text { additionality. }\end{array}$ & $\begin{array}{l}\text { Very limited } \\
\text { evidence. } \\
\text { Some evidence } \\
\text { suggesting lack of } \\
\text { reallocation of } \\
\text { firms from inside } \\
\text { to outside zone. }\end{array}$ & No (4); low (1) & No (4); low (1) & No (4); low (1) & 5 \\
\hline $\begin{array}{l}\text { Feminisation of } \\
\text { labour force }\end{array}$ & $\begin{array}{l}\text { Some literature exists, } \\
\text { but little evidence } \\
\text { using appropriate } \\
\text { counterfactual }\end{array}$ & $\begin{array}{l}\text { Some evidence } \\
\text { suggests } \\
\text { feminisation of } \\
\text { labour force, but } \\
\text { difficult to } \\
\text { disentangle from } \\
\text { sector composition } \\
\text { effects }\end{array}$ & $\begin{array}{l}\text { No (4); poor } \\
\text { (6); medium } \\
\text { (2); Yes (3) }\end{array}$ & No (15) & $\begin{array}{l}\text { No }(2) \text {; low (3); } \\
\text { poor (8); } \\
\text { medium (2) }\end{array}$ & 15 \\
\hline Wages & $\begin{array}{l}\text { Some literature exists, } \\
\text { mainly without } \\
\text { appropriate } \\
\text { counterfactuals, } \\
\text { although some } \\
\text { literature } \\
\text { controlling for } \\
\text { individual } \\
\text { characteristics }\end{array}$ & $\begin{array}{l}\text { Inconclusive } \\
\text { evidence. In some } \\
\text { case wages higher } \\
\text { and in some case } \\
\text { lower } \\
\text { Gender wage gap } \\
\text { also present in } \\
\text { EPZs. }\end{array}$ & $\begin{array}{l}\text { Low }(21) ; \\
\quad \text { medium (3); } \\
\text { high (3) }\end{array}$ & No (23); Yes (4) & $\begin{array}{l}\text { Good/high (3); } \\
\text { medium (2); } \\
\text { poor/low } \\
\text { (21); very } \\
\text { poor (1) }\end{array}$ & 27 \\
\hline Unionisation & $\begin{array}{l}\text { Some literature exists } \\
\text { in this area, but } \\
\text { mainly without } \\
\text { appropriate } \\
\text { counterfactual }\end{array}$ & $\begin{array}{l}\text { Unionisation banned } \\
\text { by law in some } \\
\text { EPZs. } \\
\text { Inconclusive when } \\
\text { comparing } \\
\text { unionisation inside } \\
\text { and outside zones }\end{array}$ & $\begin{array}{l}\text { No (4); low } \\
\quad(11) ; \\
\quad \text { medium (1) }\end{array}$ & No (15); Yes (1) & $\begin{array}{l}\text { Low/poor (14); } \\
\text { medium (1); } \\
\text { high (1) }\end{array}$ & 16 \\
\hline Health and safety & $\begin{array}{l}\text { Literature exists, some } \\
\text { of which with } \\
\text { appropriate study } \\
\text { designs }\end{array}$ & $\begin{array}{l}\text { Evidence of health- } \\
\text { related issues in } \\
\text { some zones. } \\
\text { Evidence mixed } \\
\text { when comparing } \\
\text { with workers } \\
\text { outside the zone }\end{array}$ & $\begin{array}{l}\text { No (7); low (8) } \\
\text { medium (2); } \\
\text { high (1) }\end{array}$ & $\begin{array}{l}\text { No (14); } \\
\text { medium (2); } \\
\text { Yes (2) }\end{array}$ & $\begin{array}{l}\text { Low (9); } \\
\text { medium (6); } \\
\text { high (3) }\end{array}$ & 18 \\
\hline Working hours & $\begin{array}{l}\text { Thin literature exists } \\
\text { with appropriate } \\
\text { study design. }\end{array}$ & $\begin{array}{l}\text { Evidence of long } \\
\text { working hours in } \\
\text { EPZs. } \\
\text { Inconclusive } \\
\text { evidence when } \\
\text { comparing with } \\
\text { workers outside } \\
\text { the zones. }\end{array}$ & $\begin{array}{l}\text { No (9); } \\
\quad \text { medium (7) }\end{array}$ & $\begin{array}{l}\text { No (15); } \\
\quad \text { medium (1) }\end{array}$ & $\begin{array}{r}\text { Very low/poor } \\
(2) ; \text { low (7); } \\
\text { medium (7) }\end{array}$ & 16 \\
\hline
\end{tabular}

No - it does not address the issue; Yes - somehow addresses the issue; low - addresses the issue to a very little extent; medium - addresses the issue to some extent and high - fully addresses the issue.

Finally, the evidence on working hours suggests that long working hours are common in EPZs, and there is evidence that in some cases this is compulsory and unremunerated. However, when comparing working hours with other firms outside the EPZ, the evidence is mixed.

Overall, the results of this synthesis suggest that although EPZs generate employment, there is no robust evidence to determine that this is additional. More importantly, the evidence reviewed suggests that EPZs do not lead unambiguously to worse labour outcomes. More and better research is, however, needed improving significantly study design and the methodologies used, especially regarding the appropriate use of counterfactuals and the choice of sample of study. 
Regarding policy, the main implication of these results is that in some cases negative labour outcomes appear to be the result of regulation derogations or of lack of law enforcement capacity in the country, rather than issues specific to the EPZs. If this is the case, countries should clearly attempt to implement and enforce labour rights and international labour standards so as to minimise negative labour outcomes. Also, the process of adoption of private standards by EPZ companies is also likely to facilitate better labour outcomes; although evidence in these areas has not been reviewed in this report. Moving away from assembling sectors may also minimise the risk of negative labour outcomes.

\section{Notes}

1. Quantifying the incentives and types of intervention would require a complete inventory of all instruments used by all EPZs included in the analysis during the period of analysis, which is impossible to achieve given the resources available. More importantly, it would require quantifying the degree of implementation and effectiveness of such measures, and the costs of implementation, which is not possible given the existing data availability.

2. One important point to highlight is that even if reallocation of workers occurs, in order to determine the additional impact on net employment we would need to determine what happens to the job vacancies left outside the zone.

3. These include Fu and Gao (2007) for China 1995-2005; Abeywardene et al. (1984) for textiles in Sri Lanka; Aggarwal (2007) for Noida, Madras and SEEPZ in India in 2001; Bhattacharya (1998) and Kabeer and Mahmud (2004) for Dhaka EPZ in Bangladesh; Chant and Mcllwaine (1995) for MACTAN EPZ and Castro (1982) for Bataan EPZ in the Philippines; ILO (2001a, 2001b) for a survey on 100 countries; Sivalingam (1994) for Malaysia; Wu (1985) and Yonghong (1989) for Guangdong and Shenzhen in China.

4. These include Fussell (2000) for Tijuana, Mexico, in 1993; Hein (1988) for apparel in Mauritius 1973-1986; Mireri (2000) for Kenya; Possas, Furtado and Carvalho (1987) in the electro-electronic sector for Brazil in 1981 (although comparing very diverse regions), and Sen and Dasgupta (2008) for West Bengal, Delhi, Haryana, Gujarat and Maharashtra in India in 2004-2006.

5. The author suggests that there are legal restrictions on unionisation in Bangladesh, Namibia, Pakistan, Nigeria, Togo, and Colombia; and on industrial action in Bangladesh, Namibia, Nigeria, Pakistan, Sri Lanka, Philippines, Turkey and India. The author also finds interference in workers' organisations' affairs in Bangladesh, Sri Lanka and Nicaragua; anti-union discrimination in the Dominican Republic, Costa Rica, Dominican Republic, India, Nicaragua, Sri Lanka, Guatemala, the Philippines; and finally action against collective bargaining in the Dominican Republic, Philippines, Sri Lanka, Malaysia, India and Nicaragua.

6. For example, ILO (2003a) documents problems of unionisation within the zones in Philippines and also argues that unionisation problems are common in factories outside the zone.

7. This contrasts with Kabeer and Mahmud (2004) also for Bangladesh, although both studies look at different periods.

8. Alvarenga and Ligia (2001) for El Salvador find that $50 \%$ of workers work $47 \mathrm{~h}$ a week, but the average outside is $49.61 \mathrm{~h}$ for industry and $47.82 \mathrm{~h}$ for textile. Kabeer and Mahmud (2004) find for Bangladesh that $30 \%$ of EPZ workers worked more than $10 \mathrm{~h}$ a day compared with $72 \%$ in the Dhaka garment factories. Finally, Mireri (2000) for Kenya finds that 10\% of EPZ employees and 18\% non-EPZ employees worked over $49 \mathrm{~h}$ per week.

9. Aggarwal (2007) suggests that for India in 2001, the majority of workers were within the legal limit of $48 \mathrm{~h}$ a week. Botchie (1984) suggests that for Liberia and Ghana the EPZ working hours guidelines are the same as other firms in the economy, but does not provide any information on whether this is followed in practice.

10. Cling, Razafindrakoto and Roubaud (2005) for Madagascar suggest that EPZ workers worked on average, $53 \mathrm{~h}$ while workers outside the zone worked an average of $44 \mathrm{~h}$ a week. Also for Madagascar, Glick and Roubaud (2006) calculate the average monthly working hours for public sector (161 h), public enterprise (172 h), private sector (187 h), EPZ (211 h) and private informal sector (180 h). Finally, Sen and Dasgupta (2008) calculate that for West Bengal, Delhi, Haryana, Gujarat and Maharashtra EPZs in India, EPZ workers work on an average $0.48 \mathrm{~h}$ a day more than their non-EPZ counterparts.

11. A robust methodology where firms would apply to be located in an EPZ and then be randomised to locate in or out of the EPZ would be very difficult to implement technically, given the low number of applicants to these zones, or legally given the potential discrimination to companies with the same characteristics. However, with the availability of more comprehensive firm data sets through censuses and industrial surveys, some quasi experimental methods could be implementing matching firms inside and outside the zones on their characteristics and evaluating their growth patterns. This could also be done at more aggregated level of the location using synthetic group methods. 


\section{Acknowledgements}

The authors would like to thank the members of their advisory board: Thomas Farole, Helson Braga and Ricardo Markwald for comments and advice during the review. Also Mahsa Yaganeh for research assistance and Charlotte Huggett and Stacey Townsend for editorial assistance. The authors would like to thank 3ie for technical assistance and for financial support.

\section{Disclosure statement}

No potential conflict of interest was reported by the authors.

\section{Funding}

Funding for this systematic review was provided by UKaid, Bill \& Melinda Gates [SR3.1406];

\section{Notes on contributors}

Xavier Cirera is a Senior Economist at the World Bank. He holds a PhD in Economics from the University of Sussex. His research focuses on innovation, trade and firm dynamics, and the effectiveness of private sector development support policies.

Rajith W. D. Lakshman is a financial economist by training with a PhD from University of Melbourne. His current research mainly focused on conflict, poverty and development within the specific area of migration (forced and voluntary) within urban contexts.

\section{References}

Abeywardene, J. R., A. De Alwis, A. Jayasena, and S. Jayaweera. 1984. Export Processing Zones in Sri Lanka: Economic Impact and Social Issues. ILO Working Paper 96. http://www.ilo.org/public/libdoc/ilo/1994/94B09_377_engl.pdf

Aggarwal, A. 2007. Impact of Special Economic Zones on Employment, Poverty and Human Development. Working Paper No. 194: Indian Council for Research on International Economic Relations (CRIER).

Aggarwal, A. 2010. "Economic Impacts of Sezs: Theoretical Approaches and Analysis of Newly Notified Sezs in India." Paper No. 20902: MPRA. http://mpra.ub.uni-muenchen.de/20902/

Alvarenga, J., and E. Ligia. 2001. La Situación Económico-Laboral De La Maquila En El Salvador: Un Análisis De Género. Paper 34: Women and Development Unit (ECLAC).

Attanapola, C. T. 2005. "Experiences of Globalization and Health in The Narratives of Women Industrial Workers in Sri Lanka." Gender, Technology and Development 9 (1): 81-102. doi:10.1177/097185240500900105.

Bhattacharya, D., 1998. Export Processing Zones in Bangladesh: Economic Impact and Social Issues. Working Paper No. 80: Multinational Enterprises Programme of ILO. http://www.ilo.org/public/libdoc/ilo/1998/98B09_79_engl.pdf

Botchie, G. 1984. Employment and Multinational Enterprises in Export Processing Zones: The Case of Liberia and Ghana. Working paper No. 30: Multinational Enterprises Programme of ILO. http://www.ilo.org/public/libdoc/ilo/1984/ 84B09_139_engl.pdf

Castro, J. S. 1982. Bataan Export Processing Zone. ILO working paper of ARTEP Project. http://www.ilo.org/public/ libdoc/ilo/1982/82B09_527_engl.pdf

Chant, S., and C. Mcllwaine. 1995. "Gender and Export Manufacturing in the Philippines: Continuity or Change in Female Employment? the Case of the Mactan Export Processing Zone." Gender, place and culture 2 (2): $147-176$. doi:10.1080/09663699550021991.

Cirera, X., and R. Lakshman. 2014. The Impact of Export Processing Zones on Employment, Wages and Labour Conditions in Developing Countries [Report]. In 3ie Systematic Review 10. London: International Initiative for Impact Evaluation (3ie).

Cling, J. P., M. Razafindrakoto, and F. Roubaud. 2005. "Export Processing Zones in Madagascar: A Success Story under Threat?" World development 33 (5): 785-803. doi:10.1016/j.worlddev.2005.01.007.

Cling, J. P., M. Razafindrakoto, and F. Roubaud. 2007. Export Processing Zones in Madagascar: The Impact of the Dismantling of Clothing Quotas on Employment and Labour Standards. Working Paper DT/2007-06: DIAL. http:// www.dial.prd.fr/dial_publications/PDF/Doc_travail/2007-06.pdf

De Armas, E. B., and M. S. Jallab. 2002. A Review of the Role and Impact of Export Processing Zones in World Trade: The Case of Mexico. GATE Working Paper 02-07: Centre National de la Recherche Scientifique. http://halshs.archivesouvertes.fr/docs/00/17/84/44/PDF/0207.pdf 
De Moya, E. F. A. 1986. Zonas Francas Industriales Y Las Empresas Multinacionales: Efectos Económicos E Impacto Sobre El Empleo En La Republica Dominicana. ILO working paper 46 of Multinational Enterprises Programme: http://www. ilo.org/public/libdoc/ilo/1986/86B09_609_SPAN.pdf

Del Prado-Lu, J. L. 2008. "Organizational Work Factors among Workers and Supervisors in Export Processing Zones Which Support Global Markets." Industrial Health 46 (5): 435-442. doi:10.2486/indhealth.46.435.

Din, M.-U. 1993. "Is an Enclave Sector a Cure for Unemployment in Ldcs?" Economics Letters 41 (4): $407-411$. doi:10.1016/0165-1765(93)90213-V.

Dunn, L. 1999. “Export Processing Zones: A Caribbean Development Dilemma." Development in practice 9 (5): $601-605$. doi:10.1080/09614529952738.

Farole, T., and G. Akinci. 2011. Special Economic Zones: Progress, Emerging Challenges, and Future Directions. Washington DC: The World Bank, Directions in Development (Trade).

Fu, X., and Y. Gao. 2007. Export Processing Zones in China: A Survey. https://www.oit.org/public/french/dialogue/ download/epzchineenglish.pdf

Fussell, E. 2000. "Making Labor Flexible: The Recomposition of Tijuana's Maquiladora Female Labor Force." Feminist Economics 6 (3): 59-79. doi:10.1080/135457000750020137.

Glick, P., and F. Roubaud. 2006. "Export Processing Zone Expansion in Madagascar: What are the Labour Market and Gender Impacts?" Journal of African Economies 15 (4): 722-756. doi:10.1093/jae/ejk016.

Gopalakrishnan, R. 2007. Freedom of Association and Collective Bargaining in Export Processing Zones: Role of the ILO Supervisory Mechanisms. Working Paper No.1: ILO. http://www.ilo.org/public/libdoc/ilo/2007/107B09_61_engl.pdf

Guendelman, S., and M. J. Silberg. 1993. "The Health Consequences of Maquiladora Work: Women on the US-Mexican Border." American Journal of Public Health 83 (1): 37-44. doi:10.2105/AJPH.83.1.37.

Gupta, M. 1994. "Duty-Free Zone, Unemployment, and Welfare a Note." Journal of Economics 59 (2): $217-236$. doi:10.1007/BF01238970.

Hamada, K. 1974. "An Economic Analysis of the Duty-Free Zone." Journal of International Economics 4 (3): $225-241$. doi:10.1016/0022-1996(74)90044-0.

Hamilton, C., and L. Svensson. 1982. "On the Welfare Effects of a 'Duty-Free Zone'." Journal of International Economics 13: 45-64. doi:10.1016/0022-1996(82)90005-8.

Hein, C. 1984. "Jobs for the Girls: Export Manufacturing in Mauritius." International Labour Review 123 (2): $251-265$.

Hein, C. 1988. Multinational Enterprises and Employment in the Mauritian Export Processing Zone. ILO working Paper No. 52 of Multinational Enterprises Programme. http://www.ilo.org/public/libdoc/ilo/1988/88B09_7_engl.pdf

Hovell, M. F., C. Sipan, C. R. Hofstetter, B. C. DuBois, A. Krefft, J. Conway, M. Jasis, and H. L. Isaacs. 1988. "Occupational Health Risks for Mexican Women: The Case of the Maquiladora along the Mexican-United States Border." International Journal of Health Services 18 (4): 617-627. doi:10.2190/1GBV-09QV-VBPP-UBT9.

ICFTU. 2003. Export Processing Zones: Symbols of Exploitation and a Development Dead-End. Brussels: International Confederation of Free Trade Unions. http://www.icftu.org/www/pdf/wtoepzreport2003-en.pdf.

ICFTU. 2004. Behind the Brand Names: Working Conditions and Labour Rights in Export Processing Zones. Brussels: International Confederation of Free Trade Unions.

ILO. 1988. Economic and Social Effects of Multinational Enterprises in Export Processing Zones. Joint publication by the United Nations Centre on Transnational Corporations and the ILO. http://www.ilo.org/public/libdoc/ilo/1988/ 88B09_332_engl.pdf.

ILO. 1996. La Situación Sociolaboral En Las Zonas Francas Y Empresas Maquiladoras Del Istmo Centroamericano Y Republica Dominicana. ILO-ACTRAV Proyecto RLA/94/MOS/NOR. http://www.ilo.org/public/libdoc/ilo/1996/96B09_420_span.pdf

ILO. 1998. Labour and Social Issues Relating to Export Processing Zones. Geneva: International Labor Organization (ILO). TMEPZ/1998.

ILO. 2001a. Seventh Survey on the Effect Given to the Tripartite Declaration of Principles Concerning Multinational Enterprises and Social Policy (Part II). Geneva: International Labor Organization (ILO). GB.280/MNE/1/2.

ILO. 2001b. Seventh Survey on the Effect Given to the Tripartite Declaration of Principles Concerning Multinational Enterprises and Social Policy (Part I). Geneva: International Labor Organization (ILO). GB.280/MNE/1/1.

ILO. 2003a. Employment and Social Policy in Respect of Export Processing Zones (Epzs). ILO GB.286/ESP/3 286th Session. http://www.ilo.org/public/libdoc/ilo/GB/286/GB.286_esp_3_engl.pdf

ILO. 2003b. A Collection of Success Stories in Organizing Women Workers and Trade Union Rights in the Philippine Export Processing Zone (Epzs). Geneva: ILO.

Joekes, S. 1987. Employment in Industrial Free Zones in the Dominican Republic: A Report with Recommendations for Improved Worker Services. Washington, DC: International Center for Research on Women. http://pdf.usaid.gov/pdf_ docs/PNAAX735.pdf.

Kabeer, N., and S. Mahmud. 2004. "Globalization, Gender and Poverty: Bangladeshi Women Workers in Export and Local Markets." Journal of international development 16 (1): 93-109. doi:10.1002/(ISSN)1099-1328.

Khan, A., S. Ullah, and K. Azam. 2010. "Individual Differences and Mental Health Disorders among Industrial Workers: A Cross Sectional Survey of Hayatabad Industrial Estate Peshawar." International Review of Business Research Papers 6 (1): 30-39.

Liberato, A. S. Q., and D. Fennell. 2007. "Gender and Well-Being in the Dominican Republic: The Impact of Free Trade Zone Employment and Female Headship." World Development 35 (3): 394-409. doi:10.1016/j.worlddev.2006.11.003. 
Mathews, D. T. 1994. Export Processing Zones in the Dominican Republic: Their Nature and Trajectory. PHD thesis: University of Sussex.

Mireri, C. 2000. "The Impact of Export Processing Zone Development on Employment Creation in Kenya." Singapore Journal of Tropical Geography 21 (2): 149-165. doi:10.1111/1467-9493.00072.

Possas, M. L., J. E. P. Furtado, and E. G. Carvalho. 1987. Employment Effects of Exports by Multinationals and of Export Processing Zones in Brazil. Geneva: International Labour Office.

Sanders, S., and D. L. Brown. 2012. "The Migratory Response of Labor to Special Economic Zones in the Philippines." Population Research and Policy Review 31 (1): 141-164. doi:10.1007/s11113-011-9220-7.

Sen, S., and B. Dasgupta. 2008. "Labour under Stress: Findings from a Survey." Economic and political weekly 43 (3): $65-72$.

Singa Boyenge, J. P. 2007. ILO Database on Export Processing Zones Revised. Working Paper 251: ILO Sectoral Activities Programme. http://www.ilo.org/public/libdoc/ilo/2007/107B09_80_engl.pdf

Sivalingam, G. 1994. Economic and Social Impact of Export Processing Zones: The Case of Malaysia. ILO Multinational Enterprises Programme Working Paper 66. http://www.ilo.org/public/libdoc/ilo/1994/94B09_366_engl.pdf

Soni-Sinha, U. 2010. "Gender, Subjectivity and Agency: A Study of Workers in Noida Export Processing Zone, India." Global Labour Journal 1 (2): 265-294. doi:10.15173/glj.v1i2.1075.

Ver Beek, K. A. 2001. "Maquiladoras: Exploitation or Emancipation? an Overview of the Situation of Maquiladora Workers in Honduras." World Development 29 (9): 1553-1567. doi:10.1016/S0305-750X(01)00057-2.

Warr, P. G. 1987. "Export Promotion via Industrial Enclaves: The Philippines' Bataan Export Processing Zone." Journal of development studies 23 (2): 220-241. doi:10.1080/00220388708422028.

Wu, C. 1985. "Forsaking the Iron Rice Bowl: Employment and Wages in China's Special Economic Zones." The Asian Journal of Public Administration 7 (2): 216-242. doi:10.1080/02598272.1985.10800166.

Yonghong, S. 1989. "Export Processing Zones in China Buji: A Case Study." Economic and political weekly 24 (7): $355-365$.

Young, L., and K. F. Miyagiwa. 1987. "Unemployment and the Formation of Duty-Free Zones." Journal of Development Economics 26 (2): 397-405. doi:10.1016/0304-3878(87)90038-1.

Zohir, S. C. 2001a. Gender Balance in the EPZ: A Socio-Economic Study of Dhaka Export Processing Zone in Bangladesh. Dhaka: Bangladesh Institute of Development Studies. http://idl-bnc.idrc.ca/dspace/bitstream/10625/28694/1/ 120869.pdf.

Zohir, S. C. 2001b. "Social Impact of the Growth of Garment Industry in Bangladesh." Bangladesh Development Studies 27 (4): 41-80.

\section{Appendix}

Appendix 1. Analysis of Heterogeneity of Results.

\begin{tabular}{|c|c|c|c|c|}
\hline Author & Country & Wages & Decade & Main sector \\
\hline Zohir (2001b) & Bangladesh & + & $1990 \mathrm{~s}$ & Clothing \\
\hline Bhattacharya (1998) & Bangladesh & + & $1990 \mathrm{~s}$ & Clothing \\
\hline Kabeer and Mahmud (2004) & Bangladesh & + & $2000 s$ & Clothing \\
\hline Possas, Furtado and Carvalho (1987) & Brazil & - & $1980 \mathrm{~s}$ & Electronics \\
\hline Fu and Gao (2007) & China & + & 1995-2005 & Various \\
\hline Wu (1985) & China & + & $1980 \mathrm{~s}$ & Textile, clothing, metal machinery, electronics \\
\hline Yonghong (1989) & China & + & 1980s & Textile, clothing, metal machinery, electronics \\
\hline ILO (2001a) & Global & + & $1990 s$ & Various \\
\hline ILO (2001b) & Global & + & $1990 \mathrm{~s}$ & Various \\
\hline Sen and Dasgupta (2008) & India & - & $2000 \mathrm{~s}$ & Various \\
\hline Aggarwal (2007) & India & + & $2000 \mathrm{~s}$ & Various \\
\hline Mireri (2000) & Kenya & - & $1990 \mathrm{~s}$ & $\begin{array}{l}\text { Clothing, printing, chemical and } \\
\text { pharmaceutical }\end{array}$ \\
\hline Glick and Roubaud (2006) & Madagascar & + & $1990 \mathrm{~s}$ & Clothing \\
\hline $\begin{array}{l}\text { Cling, Razafindrakoto and Roubaud } \\
\text { (2005) }\end{array}$ & Madagascar & 0 & 1995-2005 & Clothing \\
\hline $\begin{array}{l}\text { Cling, Razafindrakoto and Roubaud } \\
\text { (2007) }\end{array}$ & Madagascar & 0 & 1995-2006 & Clothing \\
\hline Sivalingam (1994) & Malaysia & + & $1990 \mathrm{~s}$ & Electrical, electronics, textile and garment \\
\hline Hein (1988) & Mauritius & - & $1980 s$ & Clothing \\
\hline Fussell (2000) & Mexico & - & 1990s & Textile, electronics, and machinery \\
\hline Chant and Mcllwaine (1995) & Philippines & + & $1990 \mathrm{~s}$ & Clothing and electronics \\
\hline Castro (1982) & Philippines & + & $1980 \mathrm{~s}$ & Clothing and electronics \\
\hline Warr (1987) & Philippines & 0 & $1980 \mathrm{~s}$ & Clothing and electronics \\
\hline Abeywardene et al. (1984) & Sri Lanka & + & $1980 \mathrm{~s}$ & Clothing \\
\hline
\end{tabular}

+ wages in EPZ higher than outside; 0 same or very similar level; -lower wages in EPZ than outside. 


\begin{tabular}{|c|c|c|c|c|}
\hline Author & Unionisation & Country & Decade & Main sector \\
\hline ILO (1988) & 0 & Asia & $1980 \mathrm{~s}$ & Various \\
\hline Kabeer and Mahmud (2004) & + & Bangladesh & $2000 \mathrm{~s}$ & Clothing \\
\hline Zohir (2001a) & - & Bangladesh & $1990 \mathrm{~s}$ & Clothing \\
\hline Ver Beek (2001) & - & Honduras & 1990s & Clothing \\
\hline Sen and Dasgupta (2008) & 0 & India & $2000 \mathrm{~s}$ & Various \\
\hline Mireri (2000) & + & Kenya & $1990 \mathrm{~s}$ & $\begin{array}{l}\text { Clothing, printing, chemical and } \\
\text { pharmaceutical }\end{array}$ \\
\hline $\begin{array}{l}\text { Cling, Razafindrakoto and } \\
\text { Roubaud (2005) }\end{array}$ & + & Madagascar & $1990 \mathrm{~s}$ & Clothing \\
\hline Glick and Roubaud (2006) & + & Madagascar & 1995-2005 & Clothing \\
\hline Author & Health and safety & Country & Decade & Main sector \\
\hline Zohir (2001b) & 0 & Bangladesh & $1990 \mathrm{~s}$ & Clothing \\
\hline Liberato and Fennell (2007) & - & $\begin{array}{l}\text { Dominican } \\
\text { Republic }\end{array}$ & $2000 s$ & Textile and clothing \\
\hline Ver Beek (2001) & + & Honduras & $1990 \mathrm{~s}$ & Clothing \\
\hline Botchie (1984) & + & $\begin{array}{l}\text { Liberia and } \\
\text { Ghana }\end{array}$ & 1984 & Aluminium \\
\hline Guendelman and Silberg (1993) & 0 & Mexico & $1990 \mathrm{~s}$ & $\begin{array}{l}\text { Textile, electronics and machinery- } \\
\text { assembly }\end{array}$ \\
\hline Hovell et al. (1988) & 0 & Mexico & $1990 \mathrm{~s}$ & $\begin{array}{l}\text { Textile, electronics and machinery- } \\
\text { assembly }\end{array}$ \\
\hline Attanapola (2005) & - & Sri Lanka & $2000 \mathrm{~s}$ & Clothing, shoes and toys \\
\hline Author & Working hours & Country & Decade & Main sector \\
\hline Kabeer and Mahmud (2004) & - & Bangladesh & $2000 \mathrm{~s}$ & Clothing \\
\hline Alvarenga and Ligia (2001) & - & El Salvador & $1990 \mathrm{~s}$ & Textile and clothing \\
\hline Aggarwal (2007) & 0 & India & $2000 s$ & Various \\
\hline Sen and Dasgupta (2008) & + & India & $2000 \mathrm{~s}$ & Various \\
\hline Mireri (2000) & - & Kenya & $1990 \mathrm{~s}$ & $\begin{array}{l}\text { Clothing, printing, chemical and } \\
\text { pharmaceutical }\end{array}$ \\
\hline Botchie (1984) & 0 & $\begin{array}{l}\text { Liberia and } \\
\text { Ghana }\end{array}$ & $1980 \mathrm{~s}$ & Aluminium \\
\hline $\begin{array}{l}\text { Cling, Razafindrakoto and } \\
\text { Roubaud (2005) }\end{array}$ & + & Madagascar & 1995-2005 & Clothing \\
\hline Glick and Roubaud (2006) & + & Madagascar & $1990 \mathrm{~s}$ & Clothing \\
\hline
\end{tabular}

